九州大学学術情報リポジトリ

Kyushu University Institutional Repository

\title{
Variation of Erwinia carotovora subsp. carotovora isolated from Korea
}

Seo, Sang-Tae

Laboratory of Plant Pathology, Division of Plant Pathology and Pesticide Science, Graduate School of Bioresource and Bioenvironmental Sciences, Kyushu University

Furuya, Naruto

Laboratory of Plant Pathology, Division of Plant Pathology and Pesticide Science, Department of Applied Genetics and Pest Management, Faculty of Agriculture, Kyushu University

Lim, Chun-keun

Division of Biological Enviroriment, College of agriculture and Life Sciences, Kangwon National University

Tsuchiya, Kenichi

National Institute of Agrobiological Resources T

他

https://doi.org/10.5109/24392

出版情報: 九州大学大学院農学研究院紀要. 45 (2)，pp.431-436，2001-02-28. Kyushu University バージョン：

権利関係 : 


\title{
Variation of Erwinia carotovora subsp. carotovora isolated from Korea
}

\author{
Sang-Tae Seo*, Naruto Furuya ${ }^{1}$, Chun-Keun Lim ${ }^{2}$, \\ Kenichi Tsuchiya ${ }^{3}$ and Yoichi Takanami ${ }^{1}$
}

\author{
'Laboratory of Plant Pathology, Division of Plant Pathology and Pesticide Science, \\ Department of Applied Genetics and Pest Management, Faculty of Agriculture, \\ Kyushu University, Fukuoka 812-8581, Japan \\ ${ }^{2}$ Division of Biological Environment, College of Agriculture and Life Sciences, \\ Kangwon National University, Chunchon 200-701, Korea \\ ${ }^{3}$ National Institute of Agrobiological Resources, Tsukuba 305-8602, Japan \\ (Received October 31, 2000 and accepted November 10, 2000)
}

\begin{abstract}
Twenty three Korean strains of soft rot pathogen, Erwinia carotovora subsp. carotovora $(E \mathrm{Cc})$, isolated from various kinds of plants were investigated for their bacteriological, pathological and genctic properties. On the basis of bacteriological tests, the strains were grouped into 6 biovars. Intermediate strains between $E$. carotovora subsp. carotovora and subsp. atroseptica were found (biovar B and L). The strains were divided into two pathovars based on their pathogenicity to tomato plant, onion, cucumber and potato. All the Korean strains of Ecc caused soft rot on the test plants (pathovar I), except for strain Ecc5/95 which was non pathogenic to onion (pathovar II). ERIC-PCR revealed a greater genotypic diversity with 18 profiles. Two RFLP groups were recognized when RFLP analysis was carried out for a pel gene by digesting the amplified fragments with Sau3A. Although all strains of biovar E were shown to belong to the same RFLP group, ERIC and RFLP profiles were not directly related to biovar and pathovar.
\end{abstract}

\section{INTRODUCTION}

Pectolytic erwinia cause soft rot diseases on a wide range of plants. The species Erwinia carotovora has been divided into four subspecies atroseptica (Eca), carotovora (Ecc), betavasculorum (Ecb) and wasabiae (Ecw) as stated by Darrasse et al. (1994). Eca is usually restricted to potato disease under cool temperate climate (Perombelon and Kelman, 1980). Ecb and Ecw cause soft rot of sugar beet and Japanese horseradish, respectively (Thomson et al., 1981; Goto and Matsumoto, 1987). Among the different subspecies of erwinia, Ecc strains have a world wide distribution with a wide host range. An understanding of the diversity of different strains of Ecc could be useful for formulating disease management strategies.

In the previous paper, we reported that the genetic diversity of Ecc isolated from various sources in Thailand appears to be related to their host plants and biovars in considering enterobacterial repetitive intergenic consensus (ERIC) and restriction fragment length polymorphism (RFLP) of a pel gene analyses (Seo et al., 2000).

The present study has been undertaken to characterize the Korean strains of Ecc in

* Laboratory of Plant Pathology, Division of Plant Pathology and Pesticide Science, Graduate School of Bioresource and Bioenvironmental Sciences, Kyushu University, Fukuoka 812-8581, Japan 
respect of biovar, pathovar, RFLP and ERIC profiles.

\section{MATERIALS AND METHODS}

\section{Bacterial strains and culture conditions}

Twenty three Korean strains of Ecc (Table 3 ) and four type strains of E. carotovora subsp. carotovora ATCC15713 ${ }^{\mathrm{T}}$, E. carotovora subsp. atroseptica ATCC $33260^{\mathrm{T}}, E$. carotovora subsp. betavasculorum ATCC $43762^{\mathrm{T}}$ and $E$. carotovora subsp. wasabiae ATCC $43316^{\mathrm{T}}$ were used in this study. All the strains were stored at $-70^{\circ} \mathrm{C}$ in skim milk and cultured on MGY agar (mannitol $10.0 \mathrm{~g}$, L-glutamic aicd $2.0 \mathrm{~g}, \mathrm{KH}_{2} \mathrm{PO}_{4} 0.5 \mathrm{~g}, \mathrm{NaCl}$ $0.2 \mathrm{~g}, \mathrm{MgSO}_{4} .7 \mathrm{H}_{2} \mathrm{O} 0.2 \mathrm{~g}$, yeast extract $0.25 \mathrm{~g}$, agar $15.0 \mathrm{~g}$, distilled water 1 liter, $\mathrm{pH} 7.0$ ) at $28^{\circ} \mathrm{C}$ for 2 days.

\section{Biovar determination}

The growth of the strains were tested at $36^{\circ} \mathrm{C}$ to determine the biovar of the 23 Korean strains of Ecc. A series of biochemical tests including reducing substances from sucrose, casein hydrolysis, indole production, production of acid from palatinose, sorbitol and $\alpha$-methyl glucoside was performed as described by Schaad (1980).

\section{Pathovar determination}

Pathogenicity of the strains was tested by inoculation to tomato plant (Lycopersicon esculentum Mill; Oogatafukuju), onion (Allium cepa L.; Satsuki), cucumber (Cucumis sativus L.; Nashio) and potato (Solanum tuberosum; May-Queen). Tomato plants were grown for 3-4 weeks in plastic pots of $8 \mathrm{~cm}$ diameter containing sterilized soil. Inoculation was done with bacterial suspension (conc. ca $10^{9}-10^{10} \mathrm{cells} / \mathrm{ml}$ ) by the needle pricking method. Inoculated and non-inoculated control plants were incubated in a moist chamber ( $\mathrm{RH} 95 \%$ and temperature $28^{\circ} \mathrm{C}$ ) and were observed for development of symptoms for 2-3 days after inoculation. Cucumber and potato were cut into slices while onion was cut into small pieces and the surfaces were disinfested by $70 \%$ ethyl alcohol. The slices or pieces were inoculated by the needle pricking method and put into Petri-dishes and incubated at $28^{\circ} \mathrm{C}$ for $2-3$ days.

\section{Molecular analyses}

Genomic DNA was extracted according to the method of Sambrook et al. (1989). ERIC-PCR was achieved by using primers ERIC1R and ERIC2 which are specific to the conserved repetitive sequences in bacteria (Mcmanus and Jones, 1995). Amplification was performed in a total volume of $50 \mu \mathrm{l}$ containing $67 \mathrm{mM}$ Tris- $\mathrm{HCl}$ (pH 8.8), $2.0 \mathrm{mM}$ $\mathrm{MgCl}_{2}, 0.125 \mathrm{mM}$ each of dATP, dCTP, dGTP and dTTP, 2.0 units of TaqDNA polymerase (TOYOBO, Japan), $50 \mathrm{pmol}$ each primer, and $1 \mu \mathrm{l}$ of a $50 \mathrm{ng} / \mathrm{ml}$ solution of purified DNA. PCR reactions were performed in a thermal cycler (Astec, Japan) under the following conditions; $94^{\circ} \mathrm{C}$ for $4 \mathrm{~min}$ for the first cycle, 30 cycles of $94^{\circ} \mathrm{C}$ for $1 \mathrm{~min}, 52^{\circ} \mathrm{C}$ for $1 \mathrm{~min}$ and $72^{\circ} \mathrm{C}$ for $1 \mathrm{~min}$, and a final cycle of $72{ }^{\circ} \mathrm{C}$ for $10 \mathrm{~min}$.

RFLP-PCR was done using primers $\mathrm{Y} 1$ and $\mathrm{Y} 2$, specific for $E$. carotovora (Helias et al., 1998). The volume and content of amplification reactions followed as described above. Amplification was done in the thermal cycler under the following conditions; 
35 cycles of $30 \mathrm{sec}$ at $94^{\circ} \mathrm{C}, 30 \mathrm{sec}$ at $65^{\circ} \mathrm{C}$, and $45 \mathrm{sec}$ at $72^{\circ} \mathrm{C}$. The amplification cycles were preceded by a denaturation step of $5 \mathrm{~min}$ at $95^{\circ} \mathrm{C}$ and followed by an elongation step of $10 \mathrm{~min}$ at $72^{\circ} \mathrm{C}$. RFLP analysis of pectate lyase gene was done as follows; the amplified DNA was ethanol precipitated and resuspended in $50 \mu l$ of $10 \mathrm{mM}$ Tris- $\mathrm{HCl}(\mathrm{pH} 8.0)$, $1 \mathrm{mM}$ EDTA. Aliquots of the concentrated DNA were digested with Sau $3 \mathrm{~A}$ at $37^{\circ} \mathrm{C}$ for $2 \mathrm{~h}$ in a $15 \mu l$ volume according to the manufacturer's recommendations.

\section{RESULTS AND DISCUSSION}

Erwinia carotovora subsp. carotovora strains isolated from various plants in Korea had differences in their bacteriological properties, and were grouped into 6 biovars (Table 1 and 3). Bacteriological characteristics of the strains such as ability to grow at $36^{\circ} \mathrm{C}$, to produce reducing substances from sucrose and acids from $\alpha$-methyl glucoside and palatinose are considered to be useful to distinguish Ecc and Eca (Lelliot and Dickey, 1984; Schaad, 1980). Two biovars, B and L, showed the similar properties to Eca (Table 1). The variations of biovars within Korean strains of Ecc were far greater than those of biovars within Thai strains. A little variations were also observed in the biovars of Japanese strains (Karnjanarat et al., 1987). The results of the present study are in agreement with Tanii (1984) who observed variations of Japanese strains of Ecc in their ability to produce reducing substances from sucrose and acid production from $\alpha$-methyl glucoside.

The Korean strains of Ecc were divided into two pathovars, pathovar I and II (Table 2 and 3), on the basis of their ability to cause soft rot on the test plants. All Ecc strains

Table 1. Bacteriological properties of Korean strains of Emwinia carotovora subsp. carotovora

\begin{tabular}{|c|c|c|c|c|c|c|c|c|}
\hline \multirow{2}{*}{ Charater } & \multicolumn{5}{|c|}{ Biovars } & \multirow[b]{2}{*}{$\bar{L}$} & \multirow{2}{*}{$\mathrm{Ecc}^{\mathrm{a})}$} & \multirow{2}{*}{$\mathrm{Eca}^{\mathrm{a}}$} \\
\hline & $\mathrm{B}$ & $\mathrm{D}$ & $\mathrm{E}$ & $\mathrm{F}$ & $\mathrm{G}$ & & & \\
\hline Growth at $36^{\circ} \mathrm{C}$ & + & + & + & + & + & + & + & - \\
\hline Reducing substances from sucrose & + & - & - & - & - & + & - & + \\
\hline Casein hydrolysis & + & - & + & - & + & - & + & + \\
\hline Indole production & - & - & + & + & - & - & - & - \\
\hline \multicolumn{9}{|l|}{ Acid production from } \\
\hline Palatinose & + & - & - & - & - & + & $\mathrm{w}^{\mathrm{b})}$ & + \\
\hline Sorbitol & + & - & - & - & - & + & - & - \\
\hline$\alpha$-methyl glucoside & + & - & - & - & - & - & - & + \\
\hline No. Korean strains (23) & 5 & 4 & 5 & 1 & 6 & 2 & & \\
\hline
\end{tabular}

Table 2. Differentiation of Korean strains of Emvinia carotovora subsp. carotovora into pathovar

\begin{tabular}{|c|c|c|c|c|c|}
\hline \multirow{2}{*}{ Pathovar } & \multicolumn{4}{|c|}{ Pathogenicity to } & \multirow{2}{*}{ No. of strains } \\
\hline & Onion & Tomato & Cucumber & Potato & \\
\hline I & + & + & + & + & 22 \\
\hline II & - & + & + & + & 1 \\
\hline
\end{tabular}


Table 3. Groupings of Emvinia carotovora subsp, carotovora strains by biovar, pathovar, RFLP of a pel gene and ERIC analyses

\begin{tabular}{|c|c|c|c|c|c|c|c|}
\hline Strain & Source & Isolated from & $\begin{array}{l}\text { Year } \\
\text { isolated }\end{array}$ & Biovar & Pathovar & RFLP $\left.^{3}\right)$ & $\mathrm{ERIC}^{()}$ \\
\hline Ecc $1 / 95$ & Pyungchang,Korea & Wasabi & 1995 & $\mathrm{E}$ & I & 1 & 3 \\
\hline Ecc2/95 & Inje & Chicory & " & $B$ & I & 2 & 1 \\
\hline Ecc3/95 & " & Potato & " & $\mathrm{B}$ & I & 2 & 2 \\
\hline Ecc $4 / 95$ & Wanju & Chinese cabbage & $"$ & $F$ & I & 1 & 11 \\
\hline Ecc5/95 & Chunchon & " & $"$ & $\mathrm{E}$ & II & 1 & 5 \\
\hline Ecc6/95 & Pyungchang & Potato & " & $\mathrm{E}$ & I & 1 & 3 \\
\hline $\operatorname{Eccl} / 96$ & Bonghwa & Chinese cabbage & 1996 & G & I & 2 & 4 \\
\hline Ecc $2 / 96$ & Hoengke & " & " & B & I & 2 & 6 \\
\hline $\operatorname{Ecc} 3 / 96$ & Chunchon & " & $"$ & $\mathrm{D}$ & I & 2 & 7 \\
\hline Ecc $4 / 96$ & Pyungchang & " & $"$ & $\mathrm{D}$ & I & 2 & 8 \\
\hline Ecc5/96 & Hongchon & " & " & $\mathrm{L}$ & I & 2 & 1 \\
\hline Ecc6/96 & Chunchon & Wasabi & " & $\mathrm{D}$ & I & 2 & 9 \\
\hline Ecc7/96 & " & Onion & " & $\mathrm{B}$ & I & 2 & 1 \\
\hline Ecc $8 / 96$ & Hongchon & Crisphead lettuce & " & $\mathrm{D}$ & $\mathrm{I}$ & 2 & 12 \\
\hline Ecc $9 / 96$ & Hongchon & Radish & " & $\mathrm{G}$ & I & 2 & 15 \\
\hline $\operatorname{Eccl} 1 / 96$ & Pyungchang & Potato & " & $\mathrm{L}$ & I & 2 & 1 \\
\hline $\operatorname{Eccl} 2 / 96$ & " & Cucumber & $"$ & $\mathrm{~B}$ & I & 2 & 16 \\
\hline Eccl3/96 & " & Pumpkin & $"$ & $\mathrm{G}$ & I & 2 & 13 \\
\hline Ecc14/96 & Hongchon & Potato & " & $\mathrm{G}$ & I & 2 & 10 \\
\hline Eccl/97 & Chunchon & Pepper & 1997 & $\mathrm{E}$ & I & 1 & 14 \\
\hline Ecc $2 / 97$ & Kangsung & Cala & " & $\mathrm{G}$ & I & 1 & 17 \\
\hline $\operatorname{Ecc} 3 / 97$ & Milyang & Potato & " & $\mathrm{G}$ & I & 2 & 4 \\
\hline Ecc $1 / 98$ & Kangsung & Cactus & 1998 & $\mathrm{E}$ & I & 1 & 18 \\
\hline
\end{tabular}

s) RFLP, restriction fragment length polymorphism of a pel gene

b) ERIC, enterobacterial repetitive intergenic consensus

caused soft rot in tomato plant, onion, cucumber and potato (pathovar I), except for strain Ecc5/95 that showed no pathogenicity to onion (pathovar II). Variations of pathovars within Ecc strains of Korea were less than those within Japanese strains (Karnjanarat et al., 1987)

The Korean strains of Ecc were separated into 18 profiles based on the fingerprints of ERIC-PCR (Fig. 1 and Table 3). These profiles showed that the Korean strains have wider diversity than Thai strains (Seo et al., 2000).

All products obtained by PCR for pel gene were of the expected size ( $434 \mathrm{bp}$ ) except E. carotovora subsp. betavasculorum in which no fragment was found. An RFLP analysis by digesting the amplified fragments with Sau $3 \mathrm{~A}$ was undertaken and revealed two RFLP groups (Fig. 2 and Table 3). In the previous study, most of the Thai strains of Ecc were shown to belong to the RFLP group 1 (Seo et al., 2000). In contrast, the current study indicated that most of the Korean strains of Ecc belongs to the RFLP group 2. In general, the profiles obtained from the ERIC and RFLP analyses of the Korean strains of Ecc have no direct correlation to the biovar and pathovar, although all strains of biovar $\mathrm{E}$ belong to the same RFLP group 1. 

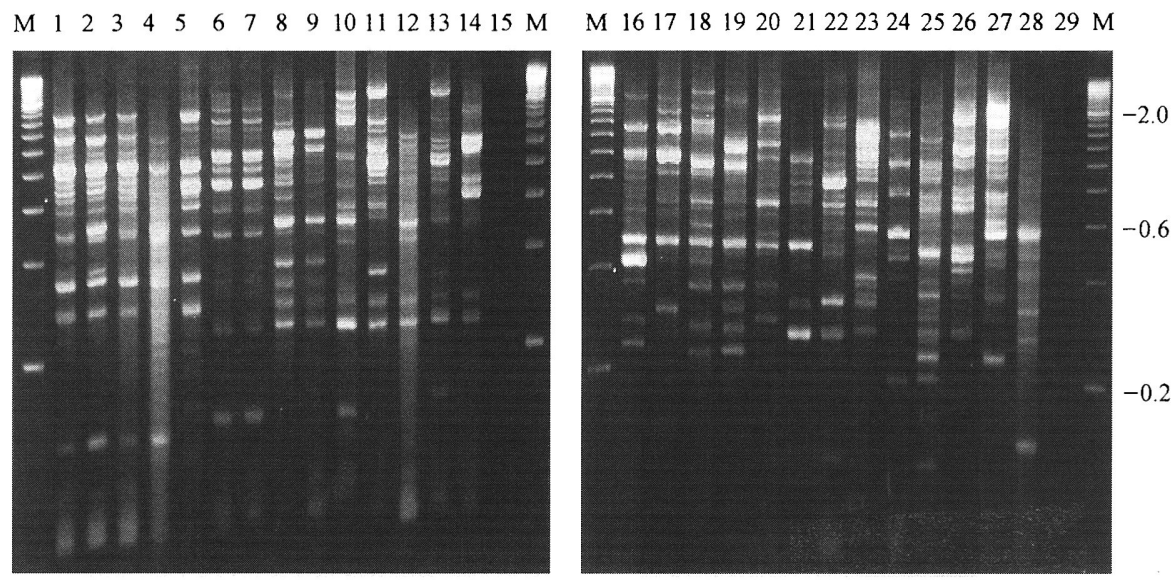

Fig. 1. ERIC-PCR patterns generated from purified DNA of E. carotovora. PCR products were separated on a $2.0 \%$ agarose gel, stained with ethidium bromide, and photographed under UV illumination. Lanes labeled $\mathrm{M}$ were run with the DNA size standard $(\mathrm{kb})$. Lane 1, Ecc2/95; Lane 2, Ecc5/96; Lane 3, Ecc7/96; Lane 4, Ecc11/96; Lane 5, Ecc3/95, Lane 6, Ecc6/95; Lane 7, Ecc1/95; Lane 8, Ecc3/97; Lane 9, Ecc1/96; Lane 10, Ecc5/95; Lane 11, Ecc2/96; Lane 12, Ecc3/96; Lane 13, Ecc4/96; Lane 14, Ecc6/96; Lane 15 and 29, the same PCR mixture but lacking template DNA (control); Lane 16, Ecc14/96; Lane 17, Ecc4/95; Lane 18, Ecc8/96; Lane 19, Ecc13/96; Lane 20, Ecc1/97; Lane 21, Ecc9/96; Lane 22, Ecc12/96; Lane 23, Ecc2/97; Lane 24, Ecc1/98; Lane 25, ATCC15713" (E. carotovora subsp. carotovora); Lane 26, ATCC33260" (E. carotovora subsp. atroseplica); Lane 27, ATCC43762 ${ }^{\mathrm{T}}$ (E. carotovora subsp. betavasculorum); Lane 28, ATCC43316 $6^{\mathrm{T}}$ (E. carotovora subsp. wasabiae)

\section{REFERENCES}

Darrasse, A., S. Priou, A. Kotoujansky and Y. Bertheau 1994 PCR and restriction fragment length polymorphism of a pel gene as a tool to identify Erwinia carotovora in relation to potato diseases. Appl. Environ. Microbiol., 60(5): 1437-1443

Goto, M and K. Matsumoto 1987 Erwinia carotovora subsp. wasabiae subsp. nov. isolated from diseased rhizomes and fibrous roots of Japanese horseradish (Eutrema wasabi Maxim.). Int. J. Syst. Bacteriol., 37: 130-135

Helias, V., A. L. Roux, Y. Bertheau, D. Andrivon, J. Gauthier and B. Jouan 1998 Characterization of Erwinia carotovora subspecies and detection of Erwinia carotovora subsp. atroseptica in potato plants, soil and water extracts with PCR-based methods. Eur. J. Plant Pathol., 104: 685-699

Karnjanarat, S., K. Tsuchiya, N. Matsuyama and S. Wakimoto 1987 Physiological, biochemical and pathological differentiation among strains of Erwinia carotovora isolated from Japan and Thailand. Ann. Phytopathol. Soc. Japan, 53: 460-469

Lelliot, R. A. and R. S. Dickey 1984 Genus VII. Erwinia Winslow, Broadhurst, Buchanan, Krumwiede, Rogers and Smith 1920, 209 ${ }^{\text {AL }}$, p.469-476. In: Krieg NR and Holt JG (eds) Bergey's manual of systematic bacteriology, vol. 1. Williams and Wilkins Co., Baltimore

Mcmanus, P. S. and A. L. Jones 1995 Genetic fingerprinting of Erwinia amylovora strains isolated from tree-fruit crops and Rubus spp.. Phytopathology, 85: 1547-1553

Perombelon, M. C. M. and A. Kelman 1980 Ecology of the soft rot erwinias. Ann. Rev. Phytopathol., 18: 361-387

Sambrook, J., E. F. Fritsch and T. Maniatis 1989 Molecular clonig: a laboratory manual, $2^{\text {nd }}$ edn. Cold 

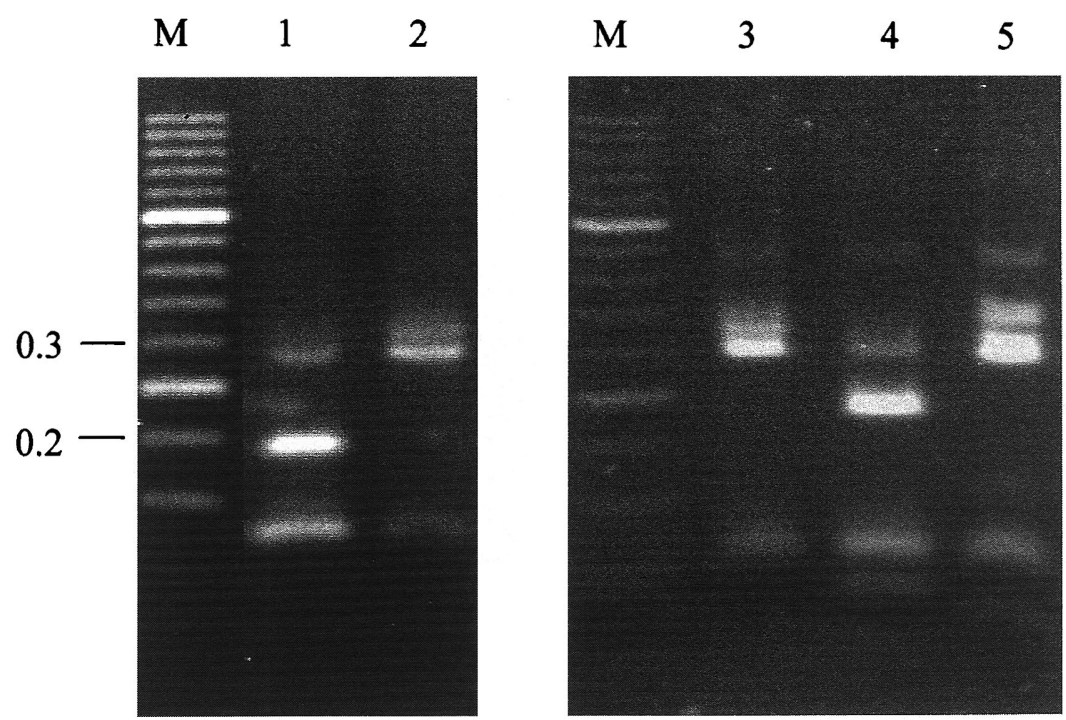

Fig. 2. RFLP analysis of the amplified fragments of a pelY gene. The DNA products were digested with restriction enzyme Sau $3 \mathrm{~A}$ and separated on a $2.5 \%$ agarose gel, stained with ethidium bromide, and photographed under UV illumination. Lanes labeled $M$ were run with the DNA size standard (kb). Lane 1, RFLP pattern 1; Lane 2, RFLP pattern 2; Lane 3, ATCC15713 (E. carotovora subsp. carotovora); Lane 4, ATCC33260 ${ }^{\mathrm{T}}$ (E. carotovora subsp. atroseptica); Lane 5, ATCC43316 ${ }^{\mathrm{T}}$ (E. carotovora subsp. wasabiae)

Spring Harbor, N. Y.

Schaad, N. W. 1980 Initial identification of common genera. In laboratory guide for identification of plant pathogenic bacteria. Edited by Schaad, N. W. Bact. Comm. Amer. Phytopath. Soc. Minn.

Seo, S. T., N. Furuya and Y. Takanami 2000 Genetic diversity in Thai strains of Erwinia carotovora subsp. carotovora based on ERIC profiles and RFLP of a pel gene. J. Fac. Agr. Kyushu Univ., 45(1): $15-19$

Tanii, A. 1984 Studies on the blackleg disease of potato in Hokkaido. Hokkaido Pref. Agr. Exp. Sta. No. 45, p 104

Thomson, S. V., D. C. Hildebrand and M. N. Schroth 1981 Identification and nutritional differentiation of the erwinia sugar beet pathogen from members of Erwinia carotovora and Erwinia chrysanthemi. Phytopathology, 71: 1037-1042 